\title{
Pengaruh Model Pembelajaran dan Kreativitas Siswa Terhadap Hasil Belajar Sejarah di SMA Islam Al-Azhar 8 Summarecon
}

\author{
Wahyudin, Tuti Nuriah, Murni Winarsih \\ SMA Islam Al-Azhar 4 Kemang Pratama Kota Bekasi \\ Wahyudin.0258@gmail.com
}

\begin{abstract}
This study aimed to find out the effect of Instructional model and student creativity toward the learning outcome of student history in SMAI Al-Azhar 8 Summarecon. The approach used was quantitative with treatment design by level $2 x 2$ experiment method. The study populations were the whole of eleventh grade students and for the sample consist 2 classes, social student 2 of eleventh grade and social student 3 of eleventh grade amount 68 students. This study instrument used that used for the student creativity was quiz and for the learning outcome was multiple choice. The survey results revealed: (1) the learning outcome that used TAI instructional model was higher than the conventional instructional model, (2) there was effect of interaction between learning model and creativity, (3) the learning outcome of student history that used TAI learning model with high creativity result revealed higher than the conventional learning model, (4) the learning model of student history with low creativity result revealed lower than the conventional learning model.

Key words: Instructional model, Student creativity, learning outcome history
\end{abstract}

\begin{abstract}
Abstrak Penelitian ini bertujuan untuk mengetahui pengaruh model pembelajaran dan kreativitas siswa terhadap hasil belajar sejarah siswa di SMAI Al-azhar 8 Summarecon. Penelitian ini merupakan penelitian kuantitaif, menggunakan metode eksperimen dengan desain treatment by level $2 \times 2$. Populasi pada penelitian ini yaitu seluruh siswa kelas XI, untuk Sampel terdiri dari dua kelas yaitu kelas XI IIS 2 dan XI IIS 3 berjumlah 68 siswa. Instrumen yang digunakan untuk Kreativitas Siswa yaitu kuesioner dan instrumen yang digunakan untuk hasil belajar yaitu tes pilihan ganda. Hasil penelitian menunjukan bahwa: (1). Hasil belajar sejarah siswa yang menggunakan model pembelajaran TAI lebih tinggi dari siswa yang menggunakan model pembelajaran konvensional, (2) terdapat pengaruh interaksi antara model pembelajaran dan kreativitas, (3) hasil belajar sejarah siswa yang menggunakan model pembelajaran TAI dengan kreativitas tinggi hasilnya lebih tinggi dari siswa yang menggunakan model pembelajaran konvensional (4) hasil belajar sejarah siswa yang menggunakan model pembelajaran TAI dengan kreativitas rendah hasilnya lebih rendah dari siswa yang menggunakan model pembelajaran langsung
\end{abstract}

Kata kunci : model pembelajaran, kreativitas, hasil belajar sejarah

\section{PENDAHULUAN}

Berdasarkan hasil observasi awal yang dilakukan peneliti di SMAI AL-Azhar 8 Sumarecon dapat diambil permasalahan sebagai berikut : mata pelajaran sejarah dianggap mata pelajaran yang kurang menarik bagi siswa dikarenakanan materi yang diajarkan hanya berupa hafalan. Selain itu Guru lebih dominan dalam proses pembelajaran sehingga proses pembelajaran dilaksanakan secara monoton dan kurang mengembangkan kreativitas siswa, hal ini berpengaruh pada hasil belajar yang didapatkan siswa. banyak 
dari siswa yang hasil belajarnya masih di bawah Kriteria Ketuntasan Minimal (KKM).

Fakta lain yang ditemukan di lapangan, guru belum mampu menciptakan situasi belajar yang menyenangkan yang dapat menarik minat siswa untuk mengikuti proses pembelajaran, Beberapa siswa belum belajar sampai pada tingkat pemahaman dalam konsep-konsep, fakta, teori pada materi pelajaran sejarah. guru belum mampu mengembangkan aspek afektif dan psikomotorik siswa, sehingga guru hanya menilai dan melihat kemampuan siswa hanya dari aspek kognitif saja.

Guru belum mampu mengembangkan kreativitas yang ada pada diri siswa, ketika guru mampu mengoptimalkan kreativitas yang ada pada diri siswa maka proses pembelajaran semakin menarik bagi siswa. Model pembelajaran yang digunakakan pada proses pembelajaran masih menggunakan model pembelajaran konvensional, guru belum mampu menggunakan model yang bervariasi sehingga pada saat di dalam kelas siwa sering merasa jenuh.

Pembelajaran sejarah seharusnya mampu mengajarakan siswa untuk mengenal lebih jauh negaranya dan mampu mengaplikasikan setiap perjuangan para pahlawan dalam kehidupan sehari-hari. Proses pembelajaran sejarah bukan hanya proses menghafal nama tahun, tokoh dan tempat, lebih jauh dari itu setiap siswa harus mampu membuat generalisasi dan menganalisis setiap peristiwa yang terjadi di masa sekararang dengan peristiwa di masa lampau. Selain itu pada proses pembejalaran seharusnya guru hanya menjadi fasilitator bagi siswa, guru harus mampu mengendalikan siswa untuk terlibat aktif di dalam kelas. Ketika siswa sudah menguasai atau mampu mendominasi kelas maka proses pembelajaran akan menarik.

Keberhasilan yang didapatkan oleh siswa bukan hanya dapat dilihat dari aspek kognitifnya saja melainkan guru harus mampu mengembangkan aspek afektif dan psikomotorik. Salah satu aspek afektif dan psikomotorik yang mampu dikembangkan oleh siswa yaitu kreativitas dalam proses pembelajaran. Guru harus mampu mengambangkan kreativitas siswa, karena setiap siswa pasti memiliki tingkat kreativitas yang berbeda-beda. Kreativitas merupakan faktor yang menjadi pendukung siswa dalam meraih keberhasilannya, dengan kreativitas yang dimiliki siswa maka siswa tersebut akan mampu mengembangkan apa yang mampu dilakukannya. Kreativitas bukan hanya menciptakan suatu benda tetapi gagasan-gagasan yang di berikan oleh siswa ketika proses pembelajaran. Menurut Jordan (2005 : 358) Kreativitas yang harus dikembangkan dikelas yaitu setiap gagasan dan ide yang ada pada diri siswa. 
Kreativitas siswa juga sangat dibutuhkan untuk menunjang proses pembelajaran. Kreativitas yang dimiliki oleh siswa mempunyai pengaruh yang besar terhadap keberhasilan proses pembelajaran, dengan penyampaian ide dan gagasan di setiap proses pembejalaran maka siswa akan mampu meningkatkan hasil belajaranya. Siswa dengan prestasi rendah tidak memiliki bekal untuk belajar materi-materi baru, sehingga dibutuhkan kerjasama dan kreativitas agar kegiatan pembelajaran dapat terserap oleh semua siswa. model pembelajaran yang cocok untuk mengembangkan kerjasama antar siswa adalah model pembelajaran kooperatif karena model ini dapat membuat pembelajaran kreatif, menyenangkan dan siswa menjadi aktif dalam kegiatan pembelajaran.

Berdasarkan permasalahan yang dikemukakan di atas maka penelitian ini dilakukan untuk mengoptimalkan Kreativitas siswa yang nantinya berpengaruh terhadap hasil belajar siswa setelah proses pembelajaran berlangsung. Salah satu model pembelajaran yang diduga dapat mengoptimalkan Kreativitas siswa yaitu model pembelajaran cooperative learning tipe Team Asissted Individualisation. Penelitian ini dikhususkan untuk mengetahui pengaruh model pembelajaran dan kreativitas siswa terhadap hasil belajar siswa pada mata pelajaran sejarah SMAI Al-azhar 8 Summarecon Bekasi.

Gagne (2005:48) mengkategorikan lima kemampuan dalam capaian hasil belajar yaitu, keterampilan intelektual, strategi kognitif, sikap, informasi verbal dan keterampilan motorik. Lebih jauh Gagne menjelaskan hasil belajar yang harus dicapai setiap siswa dalam proses pembelajaran meliputi lima aspek. Slavin (2005:187) model pembelajaran TAI mengadaptasi dari perbedaan individual yang berkaitan dengan kemampuan siswa maupun prestasi siwa tetapi dalam satu kelompok diskusi.

Spector dkk (2013:299) berpendapat bahwa pembelajaran langsung adalah pembelajaran yang melibatkan guru atau tutor atau sistem intruksional dalam membuat keputusan kepada siswa terhadap sumber belajar yang akan digunakan dan kegiatan yang mesti dilakukan dalam mengajar. Model pembelajaran langsung merupakan model yang secara penuh melibatkan guru, selain itu dalam model ini pengambilan keputusan diserahkan kepada guru ketika proses pembelajaran berlangsung. Craft (2007:38) menyebutkan bahwa Kreativitas adalah kecerdasan pikiran yang bekerja secara bersama-sama yang melibatkan penglihatan, berpikir dan inovasi.

Penelitian yang dilakukan oleh Ratnaningsih Indriyani (2014) yang berjudul Pengaruh model Team Assisted Individualization (TAI) terhadap hasil belajar IPS dikelas V SD Negeri Bantul. Dalam penelitian ini dapat diketahui 
bahwa adanya adanya pengaruh hasil belajar siswa dengan menggunakan model TAI.

Tujuan penelitian ini yaitu, (1) Perbedaan hasil belajar dalam pembelajaran sejarah siswa yang menggunakan model pembelajaran cooperative learning tipe TAI dengan model pembelajaran konvensional (2) Pengaruh interaksi antara model pembelajaran dan kreativitas siswa terhadap hasil belajar. (3) Perbedaan Hasil belajar sejarah siswa yang menggunakan model pembelajaran Cooperative Learning tipe TAI dengan model pembelajaran konvensional pada siswa yang memiliki kreativitas tinggi. (4) Perbedaan Hasil belajar sejarah siswa yang menggunakan model pembelajaran Cooperative Learning tipe TAI dengan model pembelajaran konvensional pada siswa yang memiliki kreativitas rendah

\section{METODE}

Metode yang digunakan dalam penelitian ini yaitu eksperimen dengan Desain Treatmen by level $2 \times 2$. Variabel dalam penelitian ini terdiri dari dua variabel bebas yaitu model pembelajaran Cooperative Learning tipe TAI dan model pembelajaran langsung. Sedangkan variabel terikat dalam penelitian ini yaitu hasil belajar sejarah. Penelitian ini merupakan penelitian eksperimen menggunakan satu kelas eksperimen dengan model pembelajaran cooperative learning tipe TAI dan satu kelas kontrol dengan model pembelajaran langsung. Populasi dalam penelitian ini yaitu seluruh siswa kelas XI jurusan IIS yang berjumlah Tiga kelas total seluruh populasi yaitu 102 siswa, sampel yang diambil dalam penelitian ini yaitu kelas XI IIS 2 sebagai kelas eksperimen dan kelas XI IIS 3 sebagai kelas kontrol.

Pembagian siswa setelah adanya uji coba, menurut Sugiyono (2015:353) Jumlah kelompok yang tinggi diambil 27\% dan kelompok yang rendah $27 \%$ dari sampel uji coba. Tiap-tiap kelas diperoleh sebanyak $27 \%$ dari 34 orang yaitu 9 orang yang memiliki Kreativitas tinggi dan 9 orang yang memiliki kreativitas rendah.

Teknik pengumpulan data dalam penelitian ini yaitu instrumen hasil belajar yang berupa tes pilihan ganda dengan 50 butir soal, 5 option jawaban, 1 pilihan jawaban yang benar diberi nilai 1 dan pilihan jawaban yang salah diberi nilai 0. Uji validitas dilakukan dengan menggunakan Point Biserial Correlation $\left(\mathrm{r}_{\mathrm{pbi}}\right)$, sedangkan perhitungan realibilitas menggunakan KR 20.

Tekhnik pengumpulan data untuk kreativitas menggunakan kuesioner dalam bentuk skala likert, Uji validitas menggunakan rumus korelasi Product Moment dari Pearson. Untuk menguji reliabilitas menggunakan rumus Koefisien Alpha Cronbach, yaitu rumus yang digunakan untuk menguji reliabilitas instrumen Skala Likert. 
Analisi data dalam menggunakan uji analisis varians (ANAVA). Sebelum melakukan uji ANAVA terlebih dahulu dilakukan uji persyaratan berupa uji homogenitas dan uji normalitas. Uji normalitas dalam penelitian ini menggunakan uji liliefors, sedangkan untuk uji homogenitas menggunakan uji bartlett, pada akhir analisis menggunakan uji tuckey.

\section{HASIL}

Tabel. 1 Hasil perhitungan data analisis dua jalur (ANAVA)

\begin{tabular}{|c|c|c|c|c|c|c|}
\hline \multirow{2}{*}{ Sumber Variansi } & \multirow{2}{*}{$\mathrm{Db}$} & \multirow{2}{*}{$\mathrm{JK}$} & \multirow{2}{*}{$\mathrm{RJK}$} & \multirow{2}{*}{ F $_{\text {hitung }}$} & \multicolumn{2}{|c|}{$\mathrm{F}_{\text {tabel }}$} \\
\cline { 6 - 8 } & & & & & 0,05 & 0,01 \\
\hline Model Pembelajaran (A) & 1 & 58.78 & 58.78 & $5.391^{*}$ & 4,15 & 7,50 \\
\hline Kreativitas (B) & 1 & 113.78 & 113.78 & $7,436^{*}$ & 4,15 & 7,50 \\
\hline Interaksi (AxB) & 1 & 544.44 & 544.44 & $49.936^{* *}$ & 4,15 & 7,50 \\
\hline Dalam & 32 & 348,89 & 10,90 & & & \\
\hline Total Direduksi & 35 & 1065.89 & & & & \\
\hline
\end{tabular}

Data yang akan dideskripsikan pada bagian ini adalah tentang hasil belajar sejarah. Empat kelompok data akan dideskripsikan di bawah ini : hasil perhitungan ANAVA dua jalur diperoleh Fhitung untuk model pembelajaran sebesar 5.391 sedangkan $\mathrm{F}_{\text {tabel }}=4,15$ pada taraf nyatanya $\alpha=$ 0,05, karena nilai $F_{\text {hitung }}>\mathrm{F}_{\text {tabel }} \mathrm{l}$ maka $\left(\mathrm{H}_{0}\right)$ ditolak, dan $\mathrm{H}_{1}$ diterima. Artinya terdapat perbedaan hasil belajar sejarah antara siswa yang menggunakan model pembelajaran Cooperative Learning tipe TAI dengan siswa yang menggunakan model pembelajaran konvensional.

Hasil Fhitung menunjukkan terdapat pengaruh hasil belajar sejarah antara siswa yang menggunakan model pembelajaran Cooperative Learning tipe TAI dengan siswa yang menggunakan model pembelajaran konvensional dan dapat dilihat dari rata-rata skor model pembelajaran Cooperative Learning tipe TAI ( $\left.\mathrm{A}_{1}\right)$ 27.72, sedangkan rata-rata skor model pembelajaran konvensional $\left(\mathrm{A}_{2}\right)$ 24.67. Dapat disimpulkan hasil belajar sejarah siswa yang menggunakan model pembelajaran Cooperative Learning tipe TAI lebih tinggi dari siswa yang menggunakan model pembelajaran konvensional.

hasil perhitungan ANAVA diketahui bahwa Fhitung untuk faktor interaksi yaitu 43.722 lebih besar daripada $F_{\text {tabel }}$ yaitu 4.15 pada taraf nyata $\alpha=$ 0.05 . Terdapat pengaruh interaksi antara penggunaan model pembelajaran dan kreativitas siswa terhadap hasil belajar. Data menunjukkan bahwa $\mathrm{H}_{0}$ ditolak dan $\mathrm{H}_{1}$ diterima. Skor nilai rata-rata tiap sel diperoleh pada kelompok $\mathrm{A}_{1} \mathrm{~B}_{1}$ yaitu 32.89, $\mathrm{A}_{1} \mathrm{~B}_{2} 22.56, \mathrm{~A}_{2} \mathrm{~B}_{1} 22.56, \mathrm{~A}_{2} \mathrm{~B}_{2} 26.78$.

Hasil belajar sejarah yang memiliki kreativitas tinggi dan menggunakan model pembelajaran Cooperative Learning tipe TAI lebih tinggi 
dari siswa yang menggunakan model pembelajaran konvensional. Nilai Rata-rata hasil belajar sejarah siswa yang memiliki kreativitas tinggi dan menggunakan model pembelajaran Cooperative Learning tipe TAI (A1B1) adalah 32.89, sedangkan rata-rata hasil belajar sejarah siswa yang memiiki kreativitas tinggi dan menggunakan model pembelajaran konvensional (A2B1) adalah 22.56

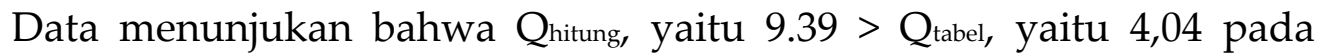
taraf signifikansinya $\alpha=0,05$. Dapat disimpulkan, bahwa $\mathrm{H}_{0}$ ditolak dan $\mathrm{H}_{1}$ diterima. Maka berarti terdapat perbedaan hasil belajar sejarah siswa yang memiliki kreativitas tinggi dan menggunakan model pembelajaran Cooperative Learning tipe TAI dan siswa yang menggunakan model pembelajaran konvensional.

Hasil belajar sejarah yang memiliki kreativitas rendah dan menggunakan model pembelajaran cooperative learning tipe TAI lebih rendah dari siswa yang menggunakan model pembelajaran konvensional. Nilai Rata-rata hasil belajar sejarah siswa yang memiliki kreativitas rendah dan menggunakan model pembelajaran cooperative learning tipe TAI (A1B2) adalah 22.56, sedangkan rata-rata hasil belajar sejarah siswa yang memiliki kreativitas rendah dan menggunakan model pembelajaran konvensional (A2B2) adalah 26.78.

Data menujukan bahwa Qhitung, yaitu $>$ Qtabel, yaitu 4,04 pada taraf signifikansinya $\alpha=0,05$, dapat disimpulkan, bahwa $\mathrm{H}_{0}$ ditolak dan $\mathrm{H}_{1}$ diterima. Terdapat perbedaan hasil belajar sejarah siswa yang memiliki kreativitas rendah yang menggunakan model pembelajaran Cooperative Learning tipe TAI dan siswa yang menggunakan model pembelajaran konvensional

\section{PEMBAHASAN}

Pengujian hipotesis yang pertama menunjukkan hasil belajar sejarah siswa yang menggunakan model pembelajaran Cooperative Learning tipe TAI lebih tinggi dari siswa yang menggunakan model pembelajaran konvensional. Pembelajaran Cooperative Learning tipe TAI merupakan perpaduan pembelajaran kelompok dan individual sehingga memperhatikan perbedaan pengetahuan awal tiap siswa untuk mencapai prestasi belajar. Menerapkan pembelajaran tersebut membuat siswa saling bekerja sama untuk membangun pengetahuan baru.

Hasil uji hipotesis untuk hipotesis kedua menunjukan bahwa terdapat pengaruh interaksi antara penggunaan model pembelajaran dan kreativitas siswa terhadap hasil belajar sejarah. Pemilihan model pembelajaran yang sesuai dengan kreativitas siswa mengakibatkan terjadinya interaksi. Memilih model pembelajaran Cooperative Learning tipe TAI sangat tepat dipadukan 
dengan kreativitas siswa, sehingga pembelajaran menjadi lebih interaktif dan komunikatif. Siswa dapat menggunakan kreativitas yang dimiliki dengan optimal pada kegiatan pembelajaran yang membutuhkan keterampilan psikomotor. Pelajaran sejarah tidak hanya menekankan pada aktivitas afektif siswa tetapi juga psikomotor. Pembelajaran sejarah yang melibatkan siswa secara interaktif berdampak pada hasil belajar yang optimal.

Hasil pengujian hipotesis ketiga menunjukan bahwa hasil belajar sejarah siswa yang memiliki kreativitas tinggi dan menggunakan model pembelajaran Cooperative Learning tipe TAI lebih tinggi dari siswa yang menggunakan model pembelajaran konvensional. Siswa yang memiliki kreativitas tinggi pandai ikut bertanggung jawab membantu teman kelompok yang kurang mampu menguasai materi. Siswa tidak hanya berharap pada bantuan guru tetapi termotivasi untuk belajar dengan cepat dan akurat. Berbeda dengan pembelajaran konvensional, pada pembelajaran Cooperative Learning tipe TAI guru hanya memerlukan sedikit waktu untuk menjelaskan materi. Siswa dengan kreativitas tinggi sangat tepat apabila belajar menggunakan model pembelajaran Cooperative Learning tipe TAI karena dapat belajar dengan mandiri tetapi juga dapat belajar dari teman sendiri. Siswa yang bekerja dalam kelompok akan membangun kondisi terbentuknya sikap positif dalam pembelajaran.

Hasil pengujian pada hipotesis keempat menyatakan hasil belajar sejarah siswa yang memiliki kreativitas rendah dan menggunakan model pembelajaran Cooperative Learning tipe TAI lebih rendah dari siswa yang menggunakan model pembelajaran konvesional. Pembelajaran konvensional yang digunakan guru lebih menekankan pada aktivitas guru sebagai sumber informasi. Siswa yang memiliki kreativitas rendah lebih menguasai materi pelajaran dan tertarik apabila penjelasan materi disampaikan secara langsung oleh guru. Siswa tidak perlu berusaha untuk membangun pengetahuan sendiri dan membantu teman kelompok menemukan solusi dalam mengerjakan tugas.

Siswa yang memiliki kreativitas tinggi apabila menggunakan model pembelajaran konvensional, tidak dapat memanfaatkan kemampuannya dalam mengimplementasikan ide-ide baru. Siswa dengan kreativitas tinggi lebih memberi diri dalam pembelajaran sehingga tidak cocok apabila kegiatan hanya berlangsung secara satu arah. Siswa dengan kreativitas rendah apabila belajar menggunakan model pembelajaran konvensional akan mendapatkan hasil belajar yang lebih optimal.

\section{KESIMPULAN}

Hasil penelitian menunjukan bahwa: (1) Hasil belajar sejarah siswa yang menggunakan model pembelajaran Cooperative Learning tipe TAI lebih 
tinggi dari siswa yang menggunakan model pembelajaran konvensional, (2) Terdapat pengaruh interaksi antara model pembelajaran dan kreativitas siswa terhadap hasil belajar sejarah, (3) Hasil belajar sejarah siswa yang menggunakan model pembelajaran Cooperative Learning tipe TAI lebih tinggi dari siswa yang menggunakan model pembelajaran konvensional, (4) Hasil belajar sejarah siswa yang menggunakan model pembelajaran Cooperative Learning tipe TAI lebih rendah dari siswa yang menggunakan model pembelajaran konvensional.

Implikasi dari penelitian ini yaitu sebagai berikut : (1) Hasil penelitian menunjukkan bahwa model pembelajaran Cooperative Learning tipe TAI dapat mengoptimalkan hasil belajar siswa. Pembelajaran menggunakan Cooperative Learning tipe TAI membuat siswa bertanggung jawab melakukan tugas secara pribadi dan kelompok. Siswa saling membantu dan mengarahkan teman yang lain yang belum bisa menguasai materi. Siswa menjadi interaktif dengan kegiatan kerjasama dalam kelompok, (2) Menentukan model pembelajaran harus mempertimbangkan karakteristik siswa termasuk kreativitas. Tingkat kreativitas siswa harus dibagi dalam tingkat tinggi dan rendah sehingga model pembelajaran dapat disesuaikan dengan hal tersebut. Siswa akan memilikii hasil belajar yang optimal apabila guru menerapkan model pembelajaran yang sesuai dengan kreativitas siswa. (3) Siswa yang memiliki kreativitas tinggi dapat belajar dengan maksimal menggunakan model pembelajaran Cooperative Learning tipe TAI. Siswa dapat memanfaatkan kreativitas yang dimiliki untuk dapat mengeluarkan ide dan gagasan baru dalam mengerjakan tugas dan memotivasi siswa lain untuk terlibat aktif dalam pembelajaran. Siswa menjadi lebih komunikatif dalam mengeluarkan pendapat, (4) Siswa yang memiliki kreativitas rendah lebih maksimal belajar menggunakan model pembelajaran konvensional. Siswa lebih menguasai materi apabila secara langsung mendengarkan penjelasan guru. Siswa dengan kreativitas rendah tidak mampu mengolah suatu informasi dengan berkerja sama dengan tim sehingga penyampaian langsung dari guru menjadi lebih bermanfaat dan dapat mengoptimalkan hasil belajar

\section{DAFTAR PUSTAKA}

[1] Craft, Anna Bob Jeffrey, dan Mike Leibling. Creativity in Education. London : Bidles Ltd., Kings Lynn, Norfolk. 2007

[2] Gagne, Robert M dan Leslie J. Briggs.(2003). Principles of Instruction Design. New York: Holt Rinehart and Winston

[3] Jedan, Starko A. Creativity in The Classroom. United Stattes: Lawrence Erlbaum Associates,2005 
[ 4 ] Spector, J Michael Barbara B Lockee, Sharon E Smaldino dan Marry C Hering. Learning, Problem Solving, and Mindtools. New York: Routledge, 2013

[ 5 ] Styhre, Alexander dan Mat Sundgren. Managing Creativity in Organizations. London : Antony Rowe,Ltd, Chippenham dan Eastbourne. 2005

[ 6 ] Slavin, Robert E. (2009).Psikologi Pendidikan: Teori dan Praktik jilid II. Jakarta: PT Indeks

[ 7 ] Sugiyono.(2015).Statistika untuk penelitian. Bandung:Alfabeta, 2015 